IN MEMORIAM

\title{
NEVILLE HOWARD MORGAN
}

1911-1973

It is sad to report the death of a much loved and esteemed friend and colleague. "Cobber" Morgan died in Sydney on December 5, 1973. He was born in Brisbane in 1911, the son of Dr T. Howard Morgan, who was surgeon to the Brisbane General Hospital. He was dux of

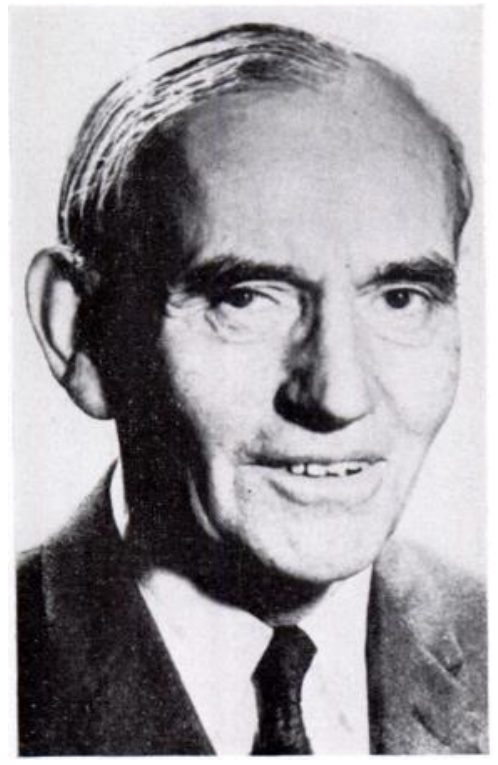
his school, won an open scholarship to the University of Queensland and completed his medical training at Sydney University, graduating in 1935 . He was a very good tennis player, cricketer and rifle shot.

Morgan was in England at the outbreak of war and enlisted there in the Australian Imperial Forces. He was posted to the Middle East, where he suffered a most serious injury when accidentally shot in the abdomen. Having recovered from this set-back he served in a field ambulance at El Alamein in the Western Desert. Later he was transferred to the Pacific theatre and commanded the 2/12 Australian Field Ambulance. At the cessation of hostilities he was the first man into Kuching to supervise the care of prisoners of war from that notorious camp. For his services he was awarded the honour of Officer of the Order of the British Empire.

After the war he returned to England, obtained the M.Ch.(Orth.) degree at Liverpool in 1947 and became a Fellow of the Royal College of Surgeons the following year. He was a member of the Derbyshire Orthopaedic and Accident Service for two years and then returned to Australia. He was then appointed to the orthopaedic staff at the Royal Prince Albert Hospital in Sydney where-his work was centred until his retirement.

In 1955 he married Roslyn Elizabeth Martin and for the next eighteen years they shared a full, happy and rewarding life. However, the later years were clouded when symptoms of Parkinson's disease developed. During this time he carried on his duties cheerfully and steadfastly, supported by his devoted wife, and earned the admiration of all his colleagues. As if this were not enough, during the last two years a series of further serious illnesses taxed his endurance to the utmost, but his courage never failed. His passing has left a vacuum among his many friends.

W. S. L. S.

\section{ALUN IOWERTH RHYDDERCH}

1918-1974

Alun Rhydderch was undoubtedly of Welsh descent, but he was always known as Rusty Ruddock. He died in Sydney on March 7, 1974, after a tragic illness which struck him down at the height of his surgical career. 